\title{
Assessment of Heavy Metal, Arsenic in Chhilpura Pond Water and its Effect on Haematological and Biochemical Parameters of Catfish, Clarias batrachus
}

\author{
Mohnish Pichhode*, Ambika Asati**, Jyotish Katare*** and S. Gaherwal*† \\ * Department of Zoology, Government Holkar (Model, Autonomous) Science College, Indore, Madhya Pradesh, India \\ **Department of Chemistry, Guru Ghasidas Vishwavidyalaya, Bilaspur, Chhatisgarh, India \\ ***Department of Pathology, Prayas Hospital, Balaghat, Madhya Pradesh, India \\ †Corresponding author: Santosh Gaherwal; psgaherwal@yahoo.com
}

Nat. Env. \& Poll. Tech.

Website: www.neptjournal.com

Received: 13-01-2020

Revised: $25-02-2020$

Accepted: 05-03-2020

Key Words:

Arsenic

Biochemistry

Clarias batrachus

Haematology

Heavy metals

\begin{abstract}
Heavy metal poisoning means an excess of the required concentration that is found naturally on earth. In the present experiment, it has been observed that the natural water source surrounded by mountains is also polluted with arsenic because these heavy metals like arsenic are naturally contained in rocks that accumulate in the water source with soil erosion and rain. In this experiment arsenic was found in the water of Chhilpura pond, in which the haematology and biochemistry of catfish (Clarias batrachus) were studied, it was found that the RBC, haemoglobin, $\mathrm{PCV}, \mathrm{MCV}, \mathrm{MCH}$, platelets, glucose and protein contents of catfish were found to be relatively low as compared to the control, whereas the WBC was observed to be higher to control and differential leucocyte count fluctuations were observed. It can be inferred from this experiment that heavy metals such as arsenic alter the haematology and biochemistry of catfish (Clarias batrachus).
\end{abstract}

\section{INTRODUCTION}

The aquatic environment is heavily degraded due to many geographical and anthropogenic activities that cause industrial and domestic effluents. Particularly, river, lakes, ponds and the reservoirs (aquatic ecosystem) situated near industrial and urban areas are the potential targets for the disposal of the environmental adverse elements like organic and inorganic contaminants (Kamaludeen et al. 2003; DeForest et al. 2007). Heavy metals are largely occurring in dispersed form in stone and rock formations. Industrialization, urbanization and anthropogenic contribution have an increasing amount of heavy metals in the biosphere and it has the largest availability in aquatic ecosystems and to a relatively smaller proportion in the atmosphere as particulates (Prakash et al. 2014; Pichhode \& Gaherwal 2019a). Heavy metals are of particular burden due to their non-biodegradable nature and their damaging effect to human health. These heavy metals have high efficiency to bioaccumulate in various organs (such as liver and kidney) and muscle tissue.

In drinking water, arsenic contamination has been reported from over 70 countries, indicating a serious health risk for an estimated 150 million people worldwide. Around 200 million people living in ten countries (including India) of South and South-East Asia are exposed to arsenic through drinking water as well as by the airborne metalloid in the areas with coal burning and industrial emissions. The level of arsenic contamination in Asian countries is more severe than the rest of the world (Agusa et al. 2008; Asati et al. 2016). The permissible limit of As-concentration in potable water was set at $50 \mu \mathrm{g} / \mathrm{L}$ in India, and the same level was followed in Bangladesh and many other countries. The World Health Organization (WHO) recommends lowering this limit to 10 $\mu \mathrm{g} / \mathrm{L}$, certified by the Bureau of Indian Standards (2003). Although well-intentioned, the infrastructure available to test and/or monitor the aggregate in India and many other countries arsenic concentration in water in the range of $10-50 \mu \mathrm{g} / \mathrm{L}$ is acceptable (Compounds 2001, Acharyya 2005). Arsenic is a natural ubiquitous element and it occurs in several environmental segments as a result of natural and anthropogenic activities, while anthropogenic sources include mining activity, use of pesticides (insecticides, herbicides and rodenticides) and many types of wood preservatives which result in contamination of soil and other related substances (Baldissarelli et al. 2012, Aruljothi et al. 2013).

Natural water resources are continuously contaminating by heavy metals and their harmful impacts on various economically important aquatic animals like fishes and others. Although the level of contamination in natural ecosystems is usually well below the limit that can cause mortality in exposed animals, it may be sufficient to impair the normal functioning of tissues (Saleh et al. 2011, Mandour et al. 2012, 
Pichhode \& Nikhil 2015a, b). These types of contaminants or pollutants cause disturbances in various physiological and biochemical mechanisms of fish. Freshwater fish are the best sentinels for monitoring and determining the health status of an aquatic ecosystem. The initial toxic effect of any contaminant is only apparent at the cellular or tissue levels and then becomes prominent in morphological or behavioural changes (Pichhode et al. 2020). Various heavy metals, agrochemicals and industrial processes continuously release various wastes into natural freshwater sources and adversely affect soil and aquatic biota monitoring. Identification and management of these pollutants are important to minimize their adverse effects on aquatic ecosystems (Witeska et al. 2014).

Arsenic contamination and their toxicity have global effects and the major arsenic repositories are freshwater. Arsenic toxicity depends on several intercellular factors that make it difficult to estimate the effect. The use of aquatic algae is often advocated for bioremediation of arsenic-contaminated water because they collect arsenate and transform it into arsenite and methylated chemical species. Fish are another major key component of aquatic ecosystems (Magellan et al. 2014). The blood shows the early effect of toxicity of arsenic in fish. It enters in the blood predominantly through extensive gill surface area where the barrier between the blood and the metal salt is very thin (Kumar \& Banerjee 2012, Pichhode \& Gaherwal 2019b) as well as through buccal cavity. Over the past several decades, fishes have been widely used as a model organism to evaluate the effects of contaminated water. Very few researchers like Roy \& Bhattacharya (2006), Singh (2007) have worked on the toxicity of arsenic in fish. The hardy nature of catfish, Clarias batrachus makes it an excellent bioindicator animal model for toxicological investigations.

Arsenic contaminated fish consumption could result in arsenic exposure to humans and lead to adverse effects on health (Kar et al. 2011). Arsenic could bring up a series of molecular events involved in oxidative stress, lipid metabolism disorder, iron homeostasis and carcinogenesis (Xu et al. 2013, Pichhode \& Gaherwal 2020). Due to the effect of arsenic, there are many changes in the biochemistry, haematology and histology of catfish, Clarias batrachus. A decrease in haemoglobin concentration, erythrocyte counts, packed cell volume, monocyte, mean corpuscular volume (MCV), mean corpuscular haemoglobin concentration (MCHC), serum total proteins and blood glucose while increased values of total leukocytes lymphocyte, serum glutamate pyruvate transaminase (SGPT) and serum glutamate oxaloacetate transaminase (SGOT) were observed in exposed fish due to arsenic. The lower values of haemoglobin concentration $(\mathrm{Hb})$ and erythrocyte counts in the study could be due to the inability of fish to carry the able amount of oxygen to hematopoietic tissue (Hussain et al. 2014, Pichhode \& Gaherwal 2019c). In this investigation, arsenic contamination in Chhilpura pond water was evaluated and study of haematology and biochemistry of Clarias batrachus was conducted.

\section{MATERIALS AND METHODS}

\section{Materials}

The material for the present study comprised of blood was taken from catfish (Clarias batrachus) that were kept in the study area water sample and laboratory condition water sample (control) for a specific exposure time.

Study area: The present investigation site was a pond of Chhilpura village, Tehsil Baihar, District Balaghat, Madhya Pradesh, India. Balaghat district is located in the southern part of Jabalpur Division (Fig. 1). It occupies the southeastern portion of the Satpura Range and the upper valley of the Wainganga river. Chhilpura is located at Madhya Pradesh and Chhatisgarh state border in latitude $22^{\circ} 18^{\prime} 55^{\prime \prime}$ and longitude $80^{\circ} 95^{\prime} 50^{\prime \prime}$ 'in the 121 kilometres north-east part away from the district headquarter according to Geological Survey of India, Toposheet No. 64 B/12 (Paul 1971) that comes in Supkhar forest reserve of Kanha National Park buffer zone and the village is surrounded by mountains and dense forests.

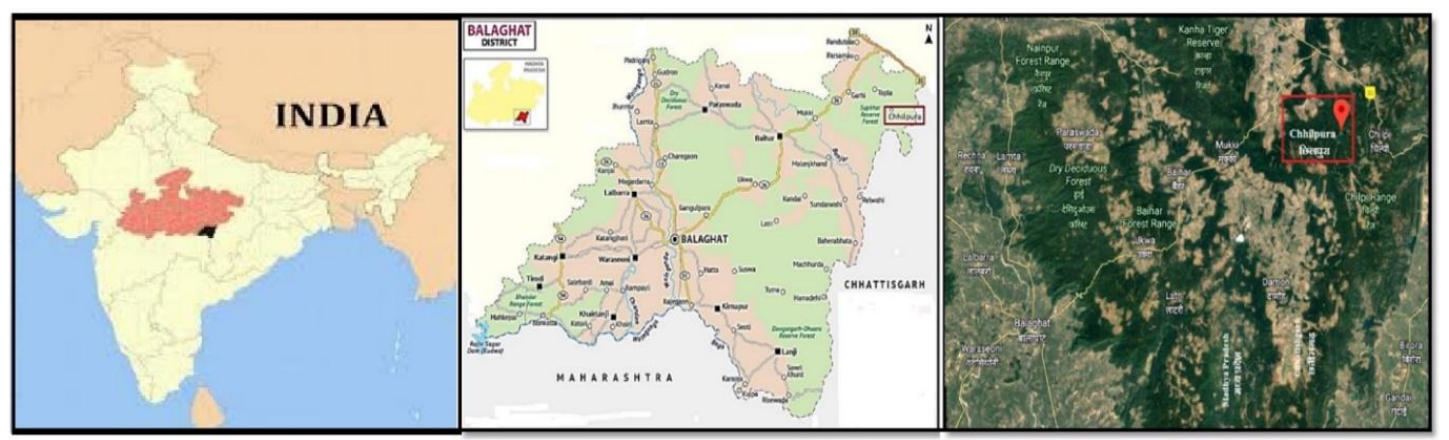

Fig. 1: Balaghat district position in India map and location of Chhilpura village, District Balaghat, Madhya Pradesh, India. 
Experimental animal: The healthy catfishes, Clarias batrachus were used as an experimental animal and it was collected from the local fish market of Indore and acclimatized to the laboratory for one week during which they were regularly fed with prawn powder and soya meal.

Collection of blood sample: The blood collected by disposable syringe and needles from cardiac puncture of Clarias batrachus and kept in sterilized appropriate vials then processed for various haematological and biochemical analyses (Dacie \& Lewis 1975).

Experimental design: In the present investigation experimental fishes were divided into two groups. Ten (10) fish were kept in the control group and exposed to normal water and forty (40) fishes were exposed to Chhilpura pond water sample.

Experimental duration: In both the control and experimental group fishes were exposed to a maximum of $96 \mathrm{hrs}$.

Experimental condition: The properties of Chhilpura pond water was tested before its use. The physicochemical conditions of sample water are given in Table 1 .

\section{Methods}

Determination of arsenic in Chhilpura pond water sample: The water was collected from study site for analysis of contamination of arsenic by adopting the method of

Table 1: Showing physicochemical conditions of Chhilpura pond sample water sample.

\begin{tabular}{|lll|}
\hline S. No. & Physicochemical Parameters & Range \\
\hline 01 & Temperature $\left({ }^{\circ} \mathrm{C}\right)$ & $30.8 \pm 0.5$ \\
02 & $\mathrm{pH}$ & $7.6 \pm 0.6$ \\
03 & Dissolved oxygen $(\mathrm{mg} / \mathrm{L})$ & $7.2 \pm 0.6$ \\
04 & Chemical oxygen demand & $14.7 \pm 0.5$ \\
& $(\mathrm{mg} / \mathrm{L})$ & \\
05 & Suspended solids $(\mathrm{mg} / \mathrm{L})$ & $39.3 \pm 1.5$ \\
06 & Chlorides $(\mathrm{mg} / \mathrm{L})$ & $17.0 \pm 1.5$ \\
07 & Hardness as $\mathrm{CaCO}(\mathrm{mg} / \mathrm{L})$ & $173.0 \pm 0.8$ \\
\hline
\end{tabular}

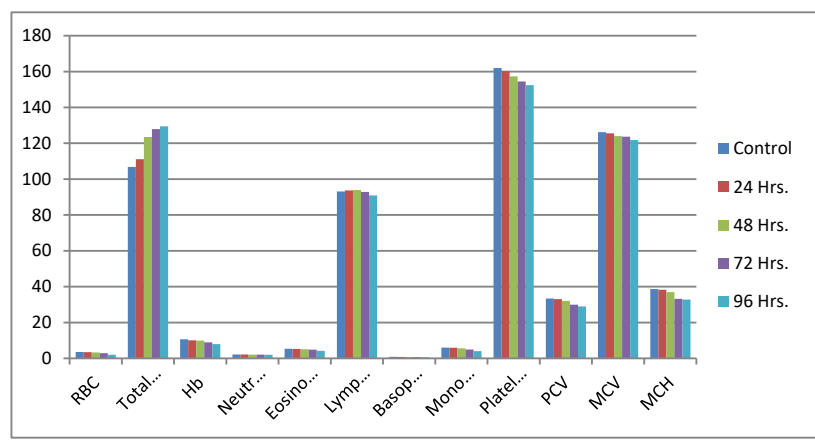

Fig. 2: Haematological changes in Clarias batrachus of Chhilpura pond water.
Feldmann (2009) and using arsenic test kit (WT025) CAS No. 387443, was taken from Himedia Laboratories Pvt. Ltd., Mumbai, India.

Haematological analysis: RBC, WBC, DLC, platelets, $\mathrm{PCV}, \mathrm{MCV}$ and $\mathrm{MCH}$ were counted by Haemocytometer method (Sharma \& Singh 2000). Haemoglobin concentrations were estimated by Sahil's method (Ratan 1978), differential leucocyte count by Leishman method (Rümke 1960).

Biochemical analysis: The activity of serum glutamate oxaloacetate transaminase (SGOT) and serum glutamate pyruvate transaminase (SGPT) were determined by adopting the method of Boyer (2000), total protein by biuret method (Harris 2003) and blood glucose level by Follin-wu method (Folin \& Malmros 1929).

\section{RESULTS}

In the present investigation arsenic concentration in Chhilpura pond water was found to be $0.3 \mathrm{mg} / \mathrm{L}$.

\section{Haematological Estimation}

In control group haematological values were, RBC (3.53 million/cmm), total WBC $\left(106.80 \times 10^{3} / \mathrm{cmm}\right), \mathrm{Hb}(10.64$ $\mathrm{g} / \mathrm{dL})$, Neutrophils (2.18\%), Eosinophils (5.32\%), Lymphocytes (93.12\%), Basophils (0.82\%), Monocytes (6.00\%), Platelets (162 cells/cmm), PCV (33.36\%), MCV (126.20 fl) and $\mathrm{MCH}$ (38.64 pg) (Fig. 2).

In Chhilpura pond experimental group haematological values were at the $24 \mathrm{~h} \mathrm{RBC} \mathrm{(3.44} \mathrm{million/cmm),} \mathrm{total}$ WBC $\left(111.10 \times 10^{3} / \mathrm{cmm}\right), \mathrm{Hb}(10.03 \mathrm{~g} / \mathrm{dL})$, Neutrophils (2.12\%), Eosinophils (5.24\%), Lymphocytes (93.71\%), Basophils (0.80\%), Monocytes (5.90\%), Platletes (160.20 cells/cmm), PCV (33.08\%), MCV (125.50 fl) and MCH (38.22 pg).

Moreover, in the present investigation at the $48 \mathrm{~h}$ haematological values were RBC (3.31 million/ $\mathrm{cmm}$ ), total WBC $\left(123.50 \times 10^{3} / \mathrm{cmm}\right), \mathrm{Hb}(9.90 \mathrm{~g} / \mathrm{dL})$, Neutrophils $(2.08 \%)$, Eosinophils (5.10\%), Lymphocytes (93.90\%), Basophils (0.78\%), Monocytes (5.55\%), Platletes ( 157.32 cells/cmm), $\operatorname{PCV}(32.04 \%), \operatorname{MCV}(124.00 \mathrm{fl})$ and MCH (36.94 pg).

In the present experiment at the $72 \mathrm{~h}$ haematological values were RBC (2.90 million/cmm), total WBC (127.90 $\left.\times 10^{3} / \mathrm{cmm}\right), \mathrm{Hb}(8.95 \mathrm{~g} / \mathrm{dL})$, Neutrophils $(2.04 \%)$, Eosinophils (4.84\%), Lymphocytes (92.84\%), Basophils (0.73\%), Monocytes (4.91\%), Platelets (154.50 cells/cmm), PCV (29.98\%), MCV (123.70 fl) and MCH (33.18 pg).

In the present investigation at the $96 \mathrm{~h}$ haematological values were RBC (2.00 million/cmm), total WBC (129.44 $\left.\times 10^{3} / \mathrm{cmm}\right), \mathrm{Hb}(7.92 \mathrm{~g} / \mathrm{dL})$, Neutrophils $(1.98 \%)$, Eosino- 
phils (4.16\%), Lymphocytes (90.90\%), Basophils (0.61\%), Monocytes (4.02\%), Platelets (152.44 cells/cmm), PCV (28.93\%), MCV (121.5 fl) and MCH (32.78 pg).

In the present investigation due to arsenic-contaminated water of Chhilpura pond ( $0.3 \mathrm{mg} / \mathrm{L}) \mathrm{RBC}, \mathrm{Hb}$, Neutrophils, Eosinophils, Basophils, Monocytes, Platelets, PCV, MCV and $\mathrm{MCH}$ values were decreased as compared to control value at $24,48,72$ and $96 \mathrm{~h}$. Total $\mathrm{WBC}$ values were increased at 24, 48, 72 and $96 \mathrm{~h}$ interval. Lymphocytes were also increased at 24 and $48 \mathrm{~h}$ and then decreased at 72 and $96 \mathrm{~h}$ as compared to the control value.

\section{Biochemical Estimation}

The total protein concentration, SGOT activity, SGPT activity and blood glucose level of control fishes was 5.20 $\mathrm{g} / \mathrm{dL}, 137.00 \mu \mathrm{mole} / \mathrm{L}, 42.42 \mu \mathrm{mole} / \mathrm{L}$ and $117.40 \mathrm{mg} / \mathrm{dL}$ respectively.

Total protein in blood (TP): The quantity of total protein in blood serum of experimental fishes was found decreased in Chhilpura pond water sample. The decreased total protein concentration in blood of experimental fishes after $96 \mathrm{~h}$ was 22.30 per cent. The decreased in protein value of blood after 24,48 and 72 hrs. were $3.84,4.23$ and 11.53 per cent respectively (Fig. 3).

Serum glutamate oxaloacetate transaminase activity (SGOT): The SGOT activity was found increased in Chhilpura pond water sample. The increased SGOT activity after 24, 48, 72 and $96 \mathrm{~h}$ were $0.87,3.13,3.43$ and 4.52 per cent respectively (Fig. 4).

Serum glutamate pyruvate transaminase activity (SGPT): The SGPT activity was found increased in Chhilpura pond water sample. The increased SGPT activity after $24,48,72$ and $96 \mathrm{~h}$ was $1.13,3.37,3.91$ and 5.65 per cent respectively (Fig. 5).

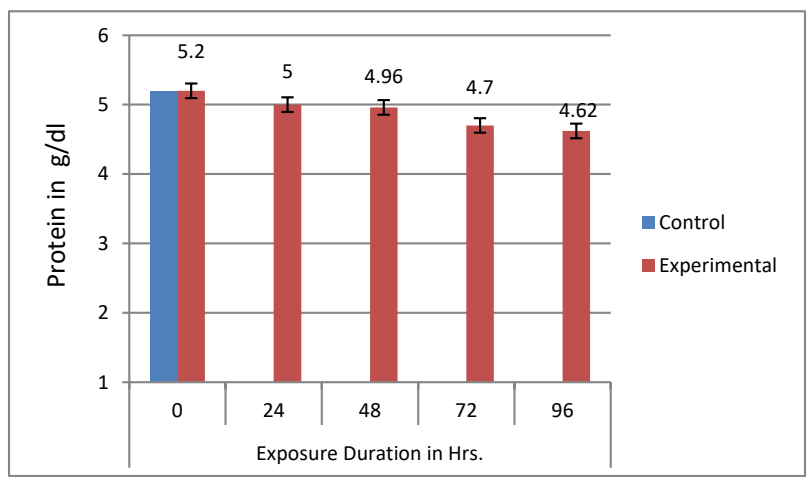

Fig. 3: Total protein in the blood of $C$. batrachus exposed to Chhilpura pond water sample $(0.3 \mathrm{mg} / \mathrm{L})$ for different durations.
Total blood glucose: The blood glucose level was found to be decreased in Chhilpura pond water samples. The decreased levels of blood glucose after 24, 48, 72 and $96 \mathrm{~h}$ were $0.68,3.74,4.77$ and 11.24 per cent respectively (Fig. 6).

In the present investigation due to arsenic-contaminated water of Chhilpura pond $(0.3 \mathrm{mg} / \mathrm{L})$ total protein and blood glucose level was decreased as compared to control at 24, 48, 72 and $96 \mathrm{~h}$ and serum glutamate oxaloacetate transaminase activity (SGOT) and serum glutamate pyruvate transaminase activity (SGPT) was increased as compared to control value at $24,48,72$ and $96 \mathrm{~h}$.

\section{DISCUSSION}

Heavy metals, such as arsenic, are one of the ten chemicals of WHO's major public health concerns. The work of the World Health Organization (WHO) to reduce and eliminate arsenic risk involves establishing guideline importance, reviewing evidence, and providing risk management recommendations. The WHO publishes a guideline value for arsenic in its guidelines for drinking water quality. The Guidelines are intended to be used as the basis for worldwide regulation and standard setting. The arsenic contents in groundwater of different countries are varied. The maximum permissible concentration of arsenic in drinking water is $50 \mu \mathrm{g} / \mathrm{L}$ and the recommended value is $10 \mu \mathrm{g} / \mathrm{L}$ (UNEPA 1975, WHO 2001).

Haematological profiles of fish are widely applied and studied to monitor environmental pollution and contaminants in aquatic ecosystems because haematological profiles are indicative of the stress and physiological status of animals (Adhikari et al. 2004). In fish, haematological parameters are commonly and frequently used to measure the toxicological effect as well as functional status of aquatic organisms by using blood (Thrall 2004). The haematological parameters include RBC, WBC, PCV, haemoglobin and other

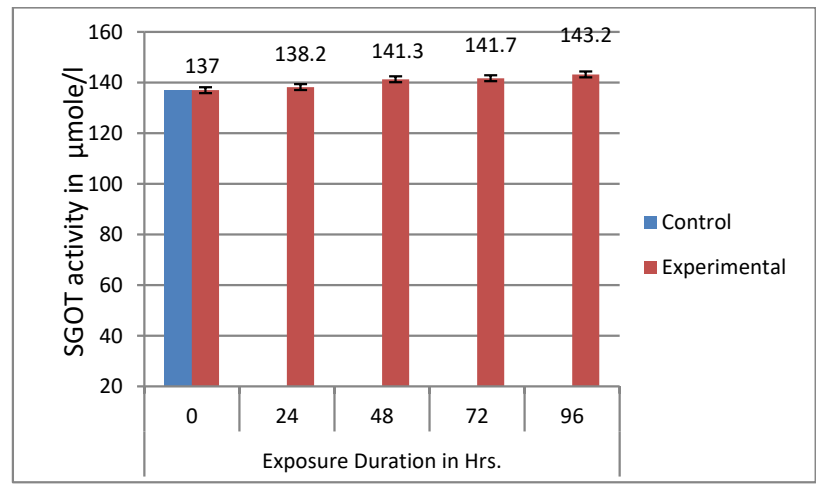

Fig. 4: SGOT activity of $C$. batrachus exposed to Chhilpura pond water sample $(0.3 \mathrm{mg} / \mathrm{L})$ for different durations. 


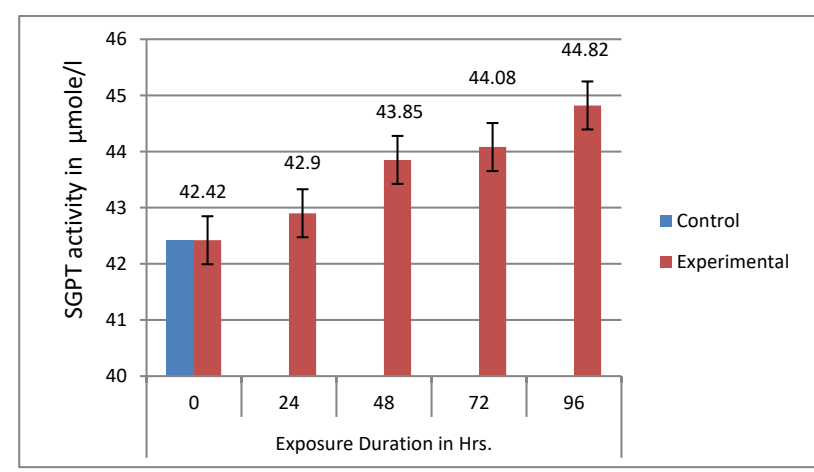

Fig. 5: SGPT activity of C. batrachus exposed to Chhilpura pond water sample $(0.3 \mathrm{mg} / \mathrm{L})$ for different durations.

haematological indices like MCV, MCH and platelets are generally used to evaluate the health status of fish (Nussey et al. 1995). The quality of water can be affected by the presence of toxins in aquatic media, which affects the value of the haematological parameters of fish due to their proximity to the external environment. Reduction of RBC, haemoglobin and PCV content in fish at arsenic risk may be due to disorder in hematopoietic processes, accelerated dissolution of RBC (Svobodova et al. 1997, Pichhode \& Gaherwal 2019d). The accumulation of arsenic in the gill region leads to haemolysis which can also be exerted at low levels of RBC. Cockel et al. (1991) found that fish treated with sub-chronic doses of arsenic represented low haemoglobin level resulting in anaemic behaviour. Arjun et al. (2002) reported that lack in the number of RBC may be caused by the interruption in erythropoiesis or by the destruction of red cells. They also reported that these changes may be due to anaemic condition and haemolysis caused by heavy metals. Another reason for the decreased amount of haemoglobin and RBC might be due to hypochromic microcytic anaemia which is contributed to the lack of iron or its decreased utilization for erythrogenesis (Natarajan 1981). A significant decrease in erythrocyte RBC counts, Haemoglobin and an increase in WBC in $C$. punctatus can be related to pollution due to the effluents (Rao \& Hymavathi 2000).

Goel \& Sharma (1987) reported some haemato-chemical characters of Clarias batrachus under arsenic metallic stress. It decreased total $\mathrm{RBC}, \mathrm{Hb} \%$ and $\mathrm{PCV}$ in Clarias batrachus from a sub-acute injection of 15 doses of $1000 \mu \mathrm{g}$ of disodium ortho arsenate indicating an anaemic condition. However, total WBC increased.

The fish were observed for the study of behavioural and/or physical changes. Blood sample $(1.50 \mathrm{~mL})$ was taken from the caudal vein of each fish at 3rd, 6th and 9th days of the experiment respectively by using with and without anticoagulant (Ethylene diamine tetra acetic acid,

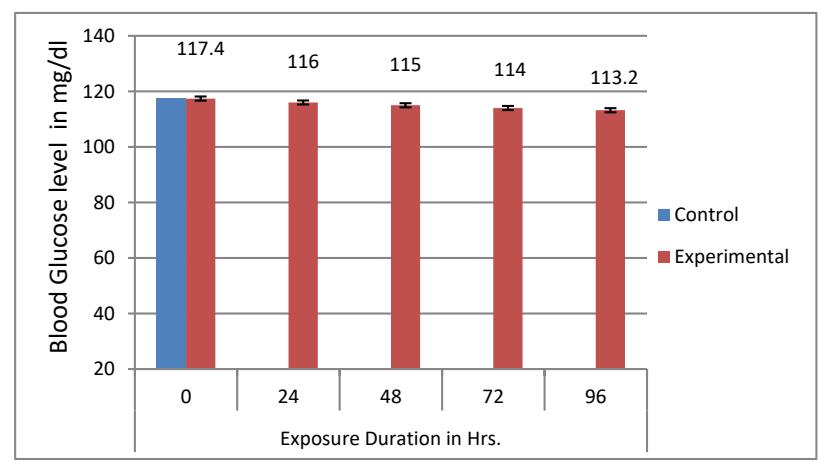

Fig. 6: Blood glucose level in C. batrachus exposed to Chhilpura pond water sample $(0.3 \mathrm{mg} / \mathrm{L})$ for different durations.

$1 \mathrm{mg} / \mathrm{mL}$ ). Haematological parameters such as leucocyte counting, haemoglobin concentration, erythrocyte counting, pack cell volume, erythrocyte indices like mean corpuscular haemoglobin, mean corpuscular haemoglobin concentration, lymphocyte and monocyte were determined (Ghaffar et al. 2014, Pichhode \& Gaherwal 2019c).

Ghaffar et al. (2016) brief the report of fish to different concentrations of arsenic showed the mixed type of impacts on different evaluated points. The combined exposure with higher concentrations significantly decreased haemoglobin concentration, erythrocyte count, corpuscular haemoglobin contents, lymphocyte, monocyte count and packed cell volume. Whereas, the leucocyte count and mean corpuscular volume were increased in respective days in fish as compared to those in the control group.

The blood parameters and haematopoietic system are known to be the best biomarkers to monitor the pathological and physiological observation of organisms exposed to various toxicants (Kousar \& Javed 2015). Furthermore, an increased degree of mean corpuscular volume can be related to an increased number of immature erythrocytes suggestive of anaemia. Decreased degree of mean corpuscular haemoglobin concentration reported as an inability of the hematopoietic system to produce haemoglobin, with inflammation in the erythrocytes.

Kumar et al. (2015) explained the impacts of the various doses of arsenic salt sodium meta-arsenite (SMA) on the blood parameters of catfish, Clarias batrachus. Mortality rate increased with increasing concentrations of arsenic salt. All the blood parameters (leucocytes count, erythrocytes, haematocrit and haemoglobin concentration) decreased with increasing concentration of toxicant and become lower at higher concentration when compared with the control. The available haematological indices of mean corpuscular haemoglobin $(\mathrm{MCH})$, mean corpuscular volume (MCV) and mean corpuscular haemoglobin concentration (MCHC) 
were equally lowered. In conclusion, the changes observed indicate that haematological parameters can be referred to as an indicator of arsenic-related stress in fish on discovering the arsenic levels. Jain \& Ali (2000) reported that the impact of arsenic induces significant alteration in haematological parameters. RBC count decreased in the exposure level, whereas, WBC count was increased at all concentration of dose-dependent arsenic treatment. The concentration of arsenic in natural water bodies mainly depends on the degree of pollution and geochemical composition. In the present study, $\mathrm{RBC}$, haemoglobin, $\mathrm{PCV}, \mathrm{MCV}, \mathrm{MCH}$ and platelets contents were decreased and increased in the number of WBC and lymphocytes due to effect of arsenic in the Chhilpura pond water $(0.3 \mathrm{mg} / \mathrm{L})$.

The decrease in the protein content of brain, gill, intestine, kidney, liver, blood and muscle has been observed in the fish exposed to nickel (Thatheyus et al. 1992). The reduction in the protein level of liver, kidney and blood has also been observed in the fish Labeo rohita exposed to pesticides due to intensive proteolysis during stress conditions (Rajamannar \& Manohar 1998). Jana \& Bondyopadhyay (1987) have reported such a reduction in protein content when the fish Channa punctatus was exposed to heavy metals such as mercury, arsenic and lead. A decrease in protein content also affects the other biochemical parameter. Depletion in tissue protein in $H$. fossilis due to copper and arsenic toxicity may be attributed to either rapid utilization of body protein or poor intake of dietary protein by fish, which support to the view of Syverson (1981) who opined that the heavy metal, in general, interferes with protein synthesis. Humtsoe et al. (2007) explained serum ALT and AST are good indicators of the overall health status of an individual especially hepatocyte injury and related stress. The increased levels of aspartate amino transferase (AST) and alanine amino transferase (ALT) enzymes also suggestive of adverse effects of arsenic and urea on the hepatocytes and abnormal cellular metabolism leading to cell death (Sharma et al. 2007, Haque \& Roy 2012). Previous studies demonstrated that basal levels of glucose varied in ecologically-distinct species, in part influenced by environmental and non-environmental factors such as feeding habits and life mode of the fish. It is reported that glucose in blood serum is the best indicator of stress in fish (Percin \& Konayalioglu 2008, Kumari et al. 2017).

The carbohydrate stored as reserve fuel in the liver and muscle tissue of fish and provides energy during acute and chronic stress (Soni et al. 2018). Glucose is referred to as an instant and immediate source of energy in stressful condition. In blood plasma reduction in carbohydrate content of the exposed fish in present investigation seems to be due to rapid utilization of blood glucose and depletion of stored glycogen to provide energy for catfish under toxicity of arsenic. Glyco- gen is the main reserve source of energy for animals during metabolism and their content in the tissue of fish exposed to chemical substance may indicate the health condition of the fish (Ananth et al. 2014). Glycogen plays an important role in carbohydrate metabolism. The unbalancing in glycogen profile was referred to as one of the most outstanding lesions to the biological system due to the mode of heavy metals (DeBruin 1976). The lower and higher concentrations of arsenic trioxide exposed the decreasing glycogen level of the liver and kidney tissues in fish Labeo rohita exhibits during the 7, 14, 21 and 28 days of exposure. The glycogen level in different tissues was less in control fish and treated fish. The significant reduction in plasma glucose levels might be due to a hypoxic situation caused by arsenic, due to an excess uses of stored carbohydrates during acute treatment (Kumari et al. 2015).

In the present investigation total protein and blood glucose level was decreased as compared to control value at 24 hours interval and Serum glutamate oxaloacetate transaminase activity (SGOT) and Serum glutamate pyruvate transaminase activity (SGPT) was increased as compared to control value at 24 hours interval due to effect of arsenic which present in Chhilpura pond water $(0.3 \mathrm{mg} / \mathrm{L})$.

\section{CONCLUSION}

Finally, we conclude that apart from geographical changes, industrialization and urbanization increase the heavy metal toxicity which causes harm to all types of organisms, especially those that live aquatic life. Similarly, arsenic has also become a worldwide problem, the standard amount of which has been set by WHO. In the present experiment, it was also seen that in such water source which is surrounded by mountains, the water flowing through the mountains in the rainy season also increases the amount of heavy metals. In future, the amount of such source can increase even more. In the present experiment, it was seen that the use of this water led to many changes in the haematology and biochemistry of Clarias batrachus, the number of RBC, haemoglobin, $\mathrm{PCV}, \mathrm{MCV}, \mathrm{MCH}$, platelets, glucose and protein contents started decreasing as well as the number of WBC, lymphocyte cell, SGOT and SGPT were increased. From this, it can be concluded that arsenic changes the haematology and biochemistry of catfish (Clarias batrachus).

\section{ACKNOWLEDGEMENT}

The authors are thankful to Head, Department of Zoology, Government Holkar (Model, Autonomous) Science College, Indore, Madhya Pradesh, India for the scientific and intellectual support during the experiment. The authors are also thankful to editors/authors/publishers of all those articles, 
journals and books from where the literature for this article has been reviewed and discussed.

\section{REFERENCES}

Acharyya, S. K. 2005. Arsenic levels in groundwater from Quaternary alluvium in the Ganga Plain and the Bengal Basin, Indian subcontinent: insights into influence of stratigraphy. Gondwana Research, 8 (1): 55-66.

Adhikari, S., Sarkar, B., Chatterjee, A., Mahapatra, C. T. and Ayyappan, S. 2004. Effects of cypermethrin and carbofuran on certain hematological parameters and prediction of their recovery in a freshwater teleost, Labeo rohita (Hamilton). Ecotoxicology and Environmental Safety, 58(2): 220-226.

Agusa, T., Takagi, K., Kubota, R., Anan, Y., Iwata, H. and Tanabe, S. 2008. Specific accumulation of arsenic compounds in green turtles (Chelonia mydas) and hawksbill turtles (Eretmochelys imbricata) from Ishigaki Island, Japan. Environmental Pollution, 153 (1): 127-136.

Ananth, S., Mathivanan, V., Aravinth, S. and Sangeetha, V. 2014. Impact of arsenic metal toxicant on biochemical changes in the grass carp, Ctenopharyngodon idella. Int. J. Mod. Res. Rev, 2: 74-78.

Arjun, J., Das, M., Dkhar, P. S., Dey, S. and Das, M. K. 2002. Role of vitamin $\mathrm{C}$ pre-treatment in reducing the blood lead level and lead-induced toxic effect in erythrocyte cell membrane. Proceedings-National Academy of Sciences India Section B, 72 (3/4): 257-266.

Aruljothi, B. 2013. Effect of arsenic on bioenzymological studies in fresh water fish, Labeo rohita. Int. J. Modern Res. and Reviews, 1(1): 13-19.

Asati, A., Pichhode, M. and Nikhil, K. 2016. Effect of heavy metals on plants: an overview. Int. J. Appl. Innov. Eng. Manage, 5: 2319-4847.

Baldissarelli, L. A., Capiotti, K. M., Bogo, M. R., Ghisleni, G. and Bonan, C. D. 2012. Arsenic alters behavioral parameters and brain ectonucleotidases activities in zebrafish (Danio rerio). Comparative Biochemistry and Physiology Part C: Toxicology Pharmacology, 155(4): 566-572.

Boyer, R. 2000. Modern Experimental Biochemistry, $3^{\text {rd }}$ ed.; Addison Wesley Longman, Inc.: California.

Bureau of Indian Standards. (22nd ed.) 2003. Indian Standard: Drinking Water Specifications. New Delhi.

Cockell, K.A., Hilton, J.W. and Bettger, W.J. 1991. Chronic toxicity of dietary disodium arsenate heptahydrate to juvenile rainbow trout (Oncorhynchus mykiss). Archives of Environmental Contamination And Toxicology, 21(4): 518-527.

Compounds, W.A. 2001. Environmental Health Criteria 224. World Health Organisation, Geneva.

Dacie, V. and Lewis, S. M. 1975. In: Practical Haematology, ELBS, Longman, Singapore, publishers.

DeBruin, A. 1976. Blood coagulation disorders. In: Biochemical Toxicology of Environmental Agents, Elsevier/North-Holland Biomedical Press Amsterdam, 1493-1481.

DeForest, D. K., Brix, K. V. and Adams, W. J. 2007. Assessing metal bioaccumulation in aquatic environments: the inverse relationship between bioaccumulation factors, trophic transfer factors and exposure concentration. Aquatic Toxicology, 84 (2): 236-246.

Feldmann, J. 2009. Onsite testing for arsenic: Field test kits. In: Reviews of Environmental Contamination, 197: 61-75. Springer, New York, NY.

Folin, O. and Malmros, H. 1929. Blood glucose determination method. J. Biol. Chem., 89: 121.

Ghaffar, A., Ashraf, S., Hussain, R., Hussain, T., Shafique, M., Noreen, S. and Aslam, S. 2014. Clinicohematological disparities induced by triazophos (organophosphate) in Japanese Quail. Pak. Vet. J., 34: 257-259.

Ghaffar, A., Hussain, R., Aslam, M., Abbas, G. and Khan, A. 2016. Arsenic and urea in combination alters the hematology, biochemistry and protoplasm in exposed Rahu Fish (Labeo rohita) (Hamilton, 1822). Turkish Journal of Fisheries and Aquatic Sciences, 16 (2): 289-296.

Goel, K. A. and Sharma, S. D. 1987. Some haematochemical characteristics of Clarias batrachus under metallic stress of arsenic. Comparative Physiology and Ecology, 12 (2): 63-66.

Haque, S. and Roy, S. K. 2012. Acute effects of arsenic on the regulation of metabolic activities in liver of fresh water fishes (Taki) during cold acclimation. Jordan Journal of Biological Sciences, 147 (618): 1-7.

Harris, D. 2003. Quantitative Chemical Analyses, $6^{\text {th }}$ ed.; W. H. Freeman and Company: USA.

Humtsoe, N., Davoodi, R., Kulkarni, B. G. and Chavan, B. 2007. Effect of arsenic on the enzymes of the rohu carp Labeo rohita (Hamilton 1822). Raffles Bull. Zool., 14: 17-19.

Hussain, R., Khan, A., Mahmood, F., Rehan, S. and Ali, F. 2014. Clinicohematological and tissue changes induced by butachlor in male Japanese quail (Coturnix japonica). Pesticide Biochemistry and Physiology, 109: 58-63.

Jain, C.K. and Ali, I. 2000. Arsenic: occurrence, toxicity and speciation techniques. Water Research, 34 (17): 4304-4312.

Jana, S. R. and Bandyopadhyaya, N. 1987. Effect of heavy metals on some biochemical parameters in the freshwater fish Channa punctatus. Environment and Ecology, 5 (3): 488-493.

Kamaludeen, S.P.B.K., Arunkumar, K.R., Avudainayagam, S. and Ramasamy, K. 2003. Bioremediation of chromium contaminated environments. Indian Journal of Experimental Biology, 41: 972-985.

Kar, S., Maity, J. P., Jean, J. S., Liu, C. C., Liu, C. W., Bundschuh, J. and Lu, H. Y. 2011. Health risks for human intake of aquacultural fish: Arsenic bioaccumulation and contamination. Journal of Environmental Science and Health, Part A, 46 (11): 1266-1273.

Kousar, S. and Javed, M. 2015. Studies on induction of nuclear abnormalities in peripheral blood erythrocytes of fish exposed to copper. Turkish Journal of Fisheries and Aquatic Sciences, 15 (4): 879-886.

Kumar, R. and Banerjee, T. K. 2012. Impact of sodium arsenite on certain biomolecules of nutritional importance of the edible components of the economically important catfish C. batrachus (Linn.). Ecology of Food and Nutrition, 51 (2): 114-127.

Kumar, R., Mishra, S. and Banerjee, T. K. 2015. Studies of dose dependent effects of sodium meta-arsenite on the blood parameters of nutritionally important catfish $C$. batrachus (Linn.). International Journal of Environment and Natural Sciences, 7: 7-12.

Kumari, B., Kumar, V. and Ahsan, J. 2015. Effect of arsenic on glucose and glycogen content in a walking catfish (Clarias batrachus). In: Conference Proceeding: World Aquaculture.

Kumari, B., Kumar, V., Sinha, A. K., Ahsan, J., Ghosh, A. K., Wang, H. and DeBoeck, G. 2017. Toxicology of arsenic in fish and aquatic systems. Environmental Chemistry Letters, 15 (1): 43-64.

Magellan, K., Barral-Fraga, L., Rovira, M., Srean, P., Urrea, G., GarcíaBerthou, E., and Guasch, H. 2014. Behavioural and physical effects of arsenic exposure in fish are aggravated by aquatic algae. Aquatic Toxicology, 156: 116-124.

Mandour, M. A., Al-Shami, S. A. and Hssein, Y. A. 2012. Effect of feeding graded levels of urea on growing New Zealand White rabbit performance. Global Vet., 9: 761-8.

Natarajan, G. M. 1981. Changes in the biomodal gas exchange and some blood parameters in the air-breathing fish, Channa striatus (Bleeker) following lethal (Lc 50/48 hrs.) exposure to metasystoc (Demeton). Current Science, 40-41.

Nussey, G., Van Vuren, J. H. J. and Du Preez, H. H. 1995. Effect of copper on blood coagulation of Oreochromis mossambicus (Cichlidae). Comparative Biochemistry and Physiology Part C: Pharmacology, Toxicology and Endocrinology, 111 (3): 359-367. 
Paul, D.K., 1971. Government of India, Geological Survey of India.

Percin, F. and Konyalioglu, S. 2008. Serum biochemical profiles of captive and wild northern bluefin tuna (Thunnus thynnus L. 1758) in the Eastern Mediterranean. Aquaculture Research, 39 (9): 945-953.

Pichhode, M. and Gaherwal, S. 2019a. Biochemical response of heavy metal, sodium arsenate exposure in catfish, Clarias batrachus. International Journal of Current Advanced Research, 8 (08), 19676-19678. DOI: http://dx.doi.org/10.24327/ijcar.2019.19678.3809

Pichhode, M. and Gaherwal, S. 2019b. Toxic effect of arsenic trioxide on biochemical response in catfish, Clarias batrachus. Int. J. Recent Sci. Res., 10 (08): 34033-34036. DOI: http://dx.doi.org/10.24327/ ijrsr.2019.1008.3804

Pichhode, M. and Gaherwal, S. 2019c. Toxicological effects of arsenic trioxide exposure on haematolical profile in catfish, Clarias batrachus. International Journal of Current Research and Review, 11(17): 09-12. DOI: http://dx.doi.org/10.31782/IJCRR.2019.11163

Pichhode, M. and Gaherwal, S. 2019d. Study of sodium arsenate induced haematological changes in catfish, Clarias batrachus. Pranama Res. J., 9 (8): 163-169.

Pichhode, M. and Gaherwal, S. 2020. Effect of heavy metal toxicity, arsenic trioxide on the biochemical parameter of fresh water fish, Clarias batrachus. Pollution Research, 39: 123-125.

Pichhode, M. and Nikhil, K. 2015b. Effect of copper mining dust on the soil and vegetation in India: a critical review. International Journal of Modern Sciences and Engineering Technology (IJMSET), 2 (2): 73-76.

Pichhode, M., Gaur, P., Khan, H. R., Dudwe, J. and Gaherwal, S. 2020. Histological alteration caused by arsenic trioxide in catfish, Clarias batrachus. Journal of Xidian University, 14 (3): 124-137.

Pichhode, M. and Nikhil, K. 2015a. Effect of copper dust on photosynthesis pigments concentration in plants species. International Journal of Engineering Research and Management (IJERM), 2 (2): 63-66.

Prakash, M. M., Gaherwal, S., Soni, R. and Nageshwar, W. 2014. Cypermethrin induced biochemical changes in kidney of Clarias batrachus. World Applied Sciences Journal, 32 (1): 18-21.

Rajamannar, K. and Manohar, L. 1998. Sublethal toxicity of certain pesticides on carbohydrates, proteins and amino acids in Labeo rohita. Journal of Ecobiology, 10 (3): 185-191.

Rao, L. M. and Hymavathi, V. 2000. Effect of slaughter house pollution on the haematological characters of Channa punctata. Pollution Research, 19 (2): 195-198.

Ratan, V. 1978. Hb\% Estimation by Sahil's Method in Handbook of Human Physiology, $3^{\text {rd }}$ edn.
Roy, S. and Bhattacharya, S. 2006. Arsenic-induced histopathology and synthesis of stress proteins in liver and kidney of Channa punctatus. Ecotoxicology and Environmental Safety, 65 (2): 218-229.

Rümke, C. L. 1960. Laboratory aids. Variability of results in differential cell counts on blood smears. Triangle; The Sandoz Journal of Medical Science, 4: 154.

Saleh, S. Y., Abdl-Rahman, M. A., Amal, A. Z. and Safaa, S. A. E. H. 2011. Growth performance, cecal fermentation and blood biochemistry of rabbits fed diet supplemented with urea-bentonite combination. Journal of Agricultural Science, 3 (1): 14.

Sharma, A., Sharma, M. K. and Kumar, M. 2007. Protective effect of Mentha piperita against arsenic induced toxicity in liver of Swiss Albino mice. Basic Clinical Pharmacology Toxicology, 100 (4): 249-257.

Sharma, I. J. and Singh, H. S. 2000. Students Laboratory Manuals of Veterinary Physiology, 1st edn. Kalyani Publisher, New Delhi, India.

Singh, A. K. 2007. Toxicopathological effect of the arsenic salt, sodium arsenate on the respiratory organs of the walking catfish Clarias batrachus (L.). Unpublished Ph. D. Dissertation, Banaras Hindu University, Varanasi, India.

Soni, R., Gaherwal, S. and Shiv, G. 2018. Effect of herbicide 2, 4-D on hematological parameters of Clarias batrachus. International Journal of Current Research in Life Sciences, 7 (07): 2441-2444.

Svobodova, Z., Groch, L., Flajšhans, M., Vykusova, B. and Machova, J. 1997. Effect of long-term therapeutic bath in malachite green on common carp (Cyprinus carpio L.). Acta Veterinaria Brno., 66 (2): 111-116.

Syverson, T. L. M. 1981. Effects of methyl mercury on protein synthesis in vitro. Acta. Pharmacol. et. Toxicol., 49: 422-426.

Thatheyus, A. J., Selvanayagam, M. and Raja, S. S. 1992. Toxicity of nickel on protein content in tissues of Cyprinus carpio communis (Linn). Indian Journal of Environmental Health, 34 (3): 236-238.

Thrall, M. A. 2004. Veterinary Haematology and Clinical Chemistry, Vol. 19. Williams and Wilkins cap, Philadelphia, PA, USA, 277-289.

United Nation Environmental Protection Agency, 1975. Interim Primary Drinking Water Standards, Fed. Reg. 40, (11): 990.

WHO, 2001. Arsenic Compounds, Environmental Health Criteria 224, 2nd ed., World Health Organisation, Geneva.

Witeska, M., Sarnowski, P., Ługowska, K. and Kowal, E. 2014. The effects of cadmium and copper on embryonic and larval development of ide Leuciscus idus L. Fish Physiology and Biochemistry, 40 (1): 151-163.

Xu, H., Lam, S. H., Shen, Y. and Gong, Z. 2013. Genome-wide identification of molecular pathways and biomarkers in response to arsenic exposure in zebra fish liver. PloS One, 8(7): e68737. 